Document downloaded from:

http://hdl.handle.net/10251/170077

This paper must be cited as:

Carricondo Antón, JM.; Oliver Villanueva, JV.; Turegano Pastor, JV.; Raigón Jiménez, MD.; González Romero, JA.; Mengual Cuquerella, J. (2020). Reduction of phosphorous from wastewater through adsorption processes reusing wood and straw ash produced in bioenergy facilities. Water Air \& Soil Pollution. 231(3):1-12. https://doi.org/10.1007/s11270020-04502-4

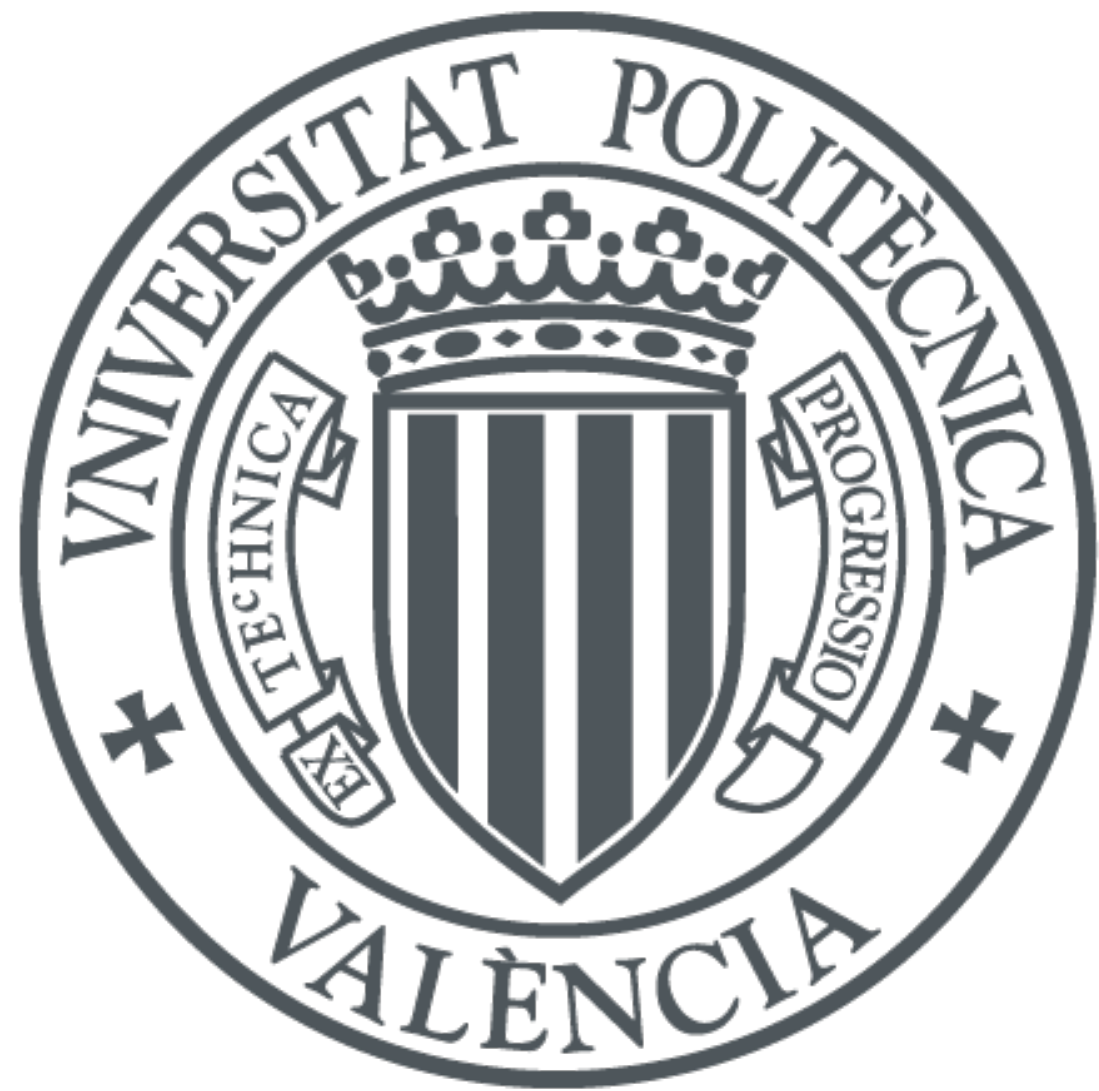

The final publication is available at

https://doi.org/10.1007/s11270-020-04502-4

Copyright Springer-Verlag

Additional Information 


\title{
Reduction of Phosphorous from Wastewater Through Adsorption Processes Reusing Wood and Straw Ash Produced in Bioenergy Facilities
}

\author{
Juan Manuel Carricondo Anton • José Vicente Oliver-Villanueva • José Vicente \\ Turégano Pastor • Maria Dolores Raigón Jiménez • Juan Andrés González Romero • \\ Jesus Mengual Cuquerella
}

Received: 13 January 2020 / Accepted: 26 February 2020

(C) Springer Nature Switzerland AG 2020

\begin{abstract}
The objective of this research is to analyse the feasibility of reusing the fly ash waste, which is produced in biomass plants, during the production of renewable energy, for controlling phosphorus contamination in the wastewater being processed in sewage treatment plants. The research examines the efficiency of using different types of ash, obtained from representative biomass materials after combustion in an energy plant (paulownia wood, wheat straw and barley straw), in removing phosphorus from water. The ashes were respectively mixed with synthetic water, rich in
\end{abstract}

phosphorus; then, using batch experiments, the effects that the pre-treatment of ash, adsorbent dosage, contact time and temperature had on the adsorption process were studied. The main results show that phosphorus adsorption by the tested ashes augments as temperature increases. Similarly, the adsorbed amount of phosphorus increases by increasing the dose of the adsorbent. In addition, the adsorption of phosphorus by these three materials has been described well by the Langmuir isotherm equation. It has been found that the removal process of phosphorus was endothermic. Finally, this

J. M. Carricondo Anton $(\bowtie) \cdot$ J. A. González Romero •

J. Mengual Cuquerella

Institute for Water and Environmental Engineering Research -

IIAMA, Universitat Politècnica de València, Camino de Vera s/n, Valencia, Spain

e-mail: juacaran@upv.es

\section{J. A. González Romero \\ e-mail: juagonr1@hma.upv.es \\ J. Mengual Cuquerella \\ e-mail: jemencu@hma.upv.es}

J. V. Oliver-Villanueva · J. V. Turégano Pastor Department of Rural Engineering - DIRA, Universitat Politècnica de València, Camino de Vera s/n, Valencia, Spain

J. V. Oliver-Villanueva e-mail: joolvil@upv.es

\section{J. V. Turégano Pastor \\ e-mail: jturegan@agf.upv.es}

\section{J. V. Oliver-Villanueva · J. V. Turégano Pastor} Institute for Information and Telecommunication Technologies ITACA, Universitat Politècnica de València, Camino de Vera $\mathrm{s} / \mathrm{n}$, Valencia, Spain

\section{D. Raigón Jiménez}

University Institute for the Conservation and Improvement of Valencian Agrodiversity, Universitat Politècnica de València, Camino de Vera s/n, Valencia, Spain

e-mail: mdraigon@qim.upv.es

\section{J. Mengual Cuquerella}

Institute of Chemical Technology, Universitat Politècnica de València - Consejo Superior de Investigaciones Científicas, Av. de los Naranjos s/n, Valencia, Spain 
study concludes that waste ash from biomass plants can be used to remove phosphorus from wastewater in sewage treatment plants.

Keywords Adsorption · Ash · Biomass · Circular economy $\cdot$ Phosphorous $\cdot$ Wastewater

\section{Introduction}

The high content of phosphorus and nitrogen in bodies of water that proceeds from wastewater and agricultural fertilization leachate generates problems of eutrophication in rivers, lakes (García-Nieto et al. 2016) and lagoons (Martín et al. 2013; Soria et al. 1987).

The European Union is determined to improve the quality of its water bodies, for instance through the removal of phosphorus, which causes eutrophication (European Commission 1991). At the same time, the $\mathrm{EU}$ is interested in reusing its critical raw materials, such as phosphorus, within a circular economy perspective (Gislev et al. 2018). Hence, it is important to make a correct use of this mineral, as well as reuse the phosphorus contained in wastewater.

The EU has emitted several directives in this respect. According to the European Directive 91/271/CEE, the limit values of phosphorus in bodies of water are $2 \mathrm{mg} \mathrm{L}^{-1}$ in agglomerations of between 10,000 and 100,000 population equivalent and $1 \mathrm{mg} \mathrm{L}^{-1}$ in larger agglomerations (European Commission 1991). Also, the European Directive 2009/28/EC has established that by 2020 at least $20 \%$ of primary energy consumption should come from renewable sources (European Commission 2009).

The production of cereal occupies a third of the cultivable surface within the European Union (European Commission 2014). For example, in Spain, $2,122,000$ ha of wheat and 3,177,000 ha of barley are produced (Schils et al. 2018). Furthermore, in different regions of Spain, the culture of using cereal residual biomass in order to generate alternative energy is being implemented (Ortiz de Zárate et al. 2005; GarcíaMaraver et al. 2012; Santamarta et al. 2014; Ubeda Delgado and Antolín Giraldo 1995).

Additionally, an effective way of producing renewable energy is to use wood from plantations or forests, reducing dependence on fossil fuels (Deboni et al. 2018). For example, Paulownia spp. plantations are being cultivated in different countries to produce biomass for the generation of energy (FernándezPuratich et al., 2014, Senelwa and Sims 1999). They are also being grown to produce energy crops (ZegadaLizarazu et al. 2010, Krasuska et al. 2010, FernándezPuratich et al. 2017), due to the rapid growth.

One of the main technical problems for energy production through biomass is the generation of waste, such as fly ash (Ortiz de Zárate et al. 2005). Biomass ashes can find applications in agriculture as fertilizer (Ingerslev et al. 2011), as well as in adsorption processes (Ahmaruzzaman 2010, Girón et al. 2013).

Phosphorus in water can be eliminated by adsorption with different biomass ashes (Mor et al. 2016). Adsorption is a process by which atoms, ions or phosphorus molecules (adsorbate) dissolved in water are retained on the solid surface of a material, in this case one of the three ashes (adsorbent).

Various scientific articles have detailed different ways of performing adsorption with biomasses, for instance the adsorption of phosphorus with rice husk (Mor et al. 2016), the adsorption of phosphorus with resins made of wheat (Liu et al. 2013) or the adsorption of nickel with barley (Thevannan et al. 2010).

Taking into account the actual state of the art, the research aims to study the elimination of phosphorus from wastewater through adsorption processes, for reducing the eutrophication problems present in the Albufera Lagoon in Valencia, reusing ash waste produced in biomass plants. The materials wheat straw ash (WSA), barley straw ash (BSA) and paulownia wood ash (PWA) are produced in biomass plants in rural areas. This biomass plants are suplied by fast-growing forest plantations for producing energy crops with as well as from residues of sylvicultural treatments (thinning or pruning). To do this, batch-type experiments using WSA, BSA and PWA allow the analysis of the effect of several parameters on the removal of phosphorus from wastewater, that is contact time, phosphate-ash ratio, ash dose and temperature.

\section{Materials and Methods}

\subsection{Preparation and Characterization of Adsorbents}

Wheat straw was obtained from wheat fields of Ademuz (Spain), geographical coordinates: $40^{\circ} 2^{\prime} 11.29^{\prime \prime} \mathrm{N}, 1^{\circ}$ $18^{\prime} 6.37^{\prime \prime} \mathrm{W}$. Barley straw was obtained from barley fields of Ademuz (Spain), geographical coordinates: 
$40^{\circ} 2^{\prime} 27.07^{\prime \prime} \mathrm{N}, 1^{\circ} 18^{\prime} 11.60^{\prime \prime} \mathrm{W}$. Paulownia was obtained from wood production fields of Paiporta (Spain), geographical coordinates: $39^{\circ} 25^{\prime} 25.13^{\prime \prime} \mathrm{N}$, $0^{\circ} 26^{\prime} 19.72^{\prime \prime} \mathrm{W}$. After combustion in a bioenergy plant located in Ademuz (Spain), the three ashes were heated at $823 \mathrm{~K}$ for $1 \mathrm{~h}$ in muffle furnaces; the WSA and PWA lost around $25 \%$ of weight and the BSA lost around $15 \%$ of weight.

Thereafter, each ash was washed with distilled water until the electric conductivity was less than $1 \mathrm{mS} \mathrm{cm}{ }^{-1}$. Following Mor et al. (2016), the ashes were dried at $378 \mathrm{~K}$ in an oven for $24 \mathrm{~h}$ to achieve constant weight and sieved again to ensure uniform particle size.

Characterization of adsorbents was done using different techniques. Nitrogen concentration was determined through the Kjeldahl method (AOAC 2000) using a Kjeltec 2100 Distillation Unit (FossTecator, Högamäs, Sweden). For the analyses of minerals, $2 \mathrm{~g}$ of the ashes was then dissolved in $2 \mathrm{~mL}$ of concentrated $\mathrm{HCl}$. The mixtures were heated until the first vapours appeared, and immediately distilled water $(2-3 \mathrm{~mL})$ was added. Subsequently, the mixtures were filtered using an ash-free filter and the extracts were brought up to $100 \mathrm{~mL}$ with distilled water. $\mathrm{K}$ and $\mathrm{Na}$ were analysed by flame photometry using a Jenway PFP7 (UK) flame photometer, and the rest of the minerals $(\mathrm{Al}, \mathrm{Ca}, \mathrm{Cd}, \mathrm{Co}$, $\mathrm{Cr}, \mathrm{Cu}, \mathrm{Fe}, \mathrm{Li}, \mathrm{Mg}, \mathrm{Mn}, \mathrm{Ni}, \mathrm{P}, \mathrm{Si}$ and $\mathrm{Zn}$ ) were analysed by inductively coupled plasma optical emission spectrometry (Agilent 700 Series ICP Optical Emission Spectrometer). Multi-element calibration standards were prepared with specific concentrations of the different elements. Table 1 shows the wavelength values used in each determination and the range of the calibration line used.

Carbon concentration was determined through the Walkley and Black method (Walkley and Black 1934) based on the Schollenberger method (Schollenberger and Simon, 1945).

The $\mathrm{pH}$ determination of the samples was determined in the aqueous extract 1:5 (ash:water) using a Crison pH\&Ion-Meter GLP 22+. The electrical conductivity measurement was determined in the aqueous extract 1:5 (ash:water) using a conductometer WTW Multi $340 \mathrm{i}$.

Three replicates were analysed for every sample; the concentration values used were the mean of the three readings.
Table 1 Elements, wavelength values and the range of the calibration line

\begin{tabular}{lll}
\hline Element & Wavelength $(\mathrm{nm})$ & $\begin{array}{l}\text { Range of the calibration } \\
\text { line }(\mathrm{ppm})\end{array}$ \\
\hline $\mathrm{Al}$ & 396.152 & $0-5$ \\
$\mathrm{Ca}$ & 317.933 & $0-50$ \\
$\mathrm{Cd}$ & 214.439 & $0-1$ \\
$\mathrm{Co}$ & 228.615 & $0-1$ \\
$\mathrm{Cr}$ & 267.716 & $0-1$ \\
$\mathrm{Cu}$ & 324.754 & $0-1$ \\
$\mathrm{Fe}$ & 259.940 & $0-5$ \\
$\mathrm{~K}$ & 766.491 & $0-50$ \\
$\mathrm{Li}$ & 460.289 & $0-1$ \\
$\mathrm{Mg}$ & 285.213 & $0-10$ \\
$\mathrm{Mn}$ & 257.610 & $0-1$ \\
$\mathrm{Na}$ & 590.000 & $0-10$ \\
$\mathrm{Ni}$ & 231.604 & $0-1$ \\
$\mathrm{P}$ & 177.434 & $0-10$ \\
$\mathrm{Si}$ & 288.158 & $0-50$ \\
$\mathrm{Zn}$ & 213.857 & $0-1$ \\
\hline
\end{tabular}

The particle morphology of the samples was studied by field emission scanning electron microscopy (FESEM), using a ZEISS Ultra5-55 microscope. Moreover, textural properties were determined by $\mathrm{N}_{2}$ adsorption-desorption isotherms measured on a Micromeritics ASAP 2020 at $77 \mathrm{~K}$.

\subsection{Adsorption Kinetics}

Adsorption isotherm experiments following Langmuir (1916), Freundlich (1906) and Temkin (1941) were conducted varying contact times from 0 to $120 \mathrm{~h}$ with initial phosphorus concentration of $80 \mathrm{mg} \mathrm{L}^{-1}$ for PWA and WSA, and $90 \mathrm{mg} \mathrm{L}^{-1}$ for BSA at different temperatures (283 K, $293 \mathrm{~K}$ and $303 \mathrm{~K})$.

The Langmuir adsorption (Langmuir 1916) is:

$q_{\mathrm{e}}=\frac{q_{\mathrm{max}} K_{\mathrm{L}} C_{\mathrm{e}}}{1+K_{\mathrm{L}} C_{\mathrm{e}}}$

where $q_{\mathrm{e}}$ is the amount of sorbate at time and equilibri$\mathrm{um}\left(\mathrm{mg} \mathrm{g}^{-1}\right), C_{\mathrm{e}}$ is the equilibrium concentration of the remaining solute in the solution $\left(\mathrm{mg} \mathrm{L}^{-1}\right), q_{\max }$ is the amount of adsorbate per mass unit of adsorbent at complete monolayer coverage $\left(\mathrm{mg} \mathrm{g}^{-1}\right)$ and $K_{\mathrm{L}}$ is the Langmuir equilibrium constant relating to the strength of adsorption $\left(\mathrm{L} \mathrm{mg}^{-1}\right)$. 
The Freundlich (Freundlich 1906) is:

$q_{\mathrm{e}}=K_{\mathrm{L}} C_{\mathrm{e}}^{\frac{1}{n}}$

where $q_{\mathrm{e}}$ is the amount of sorbate at time and equilibrium $\left(\mathrm{mg} \mathrm{g}^{-1}\right), C_{\mathrm{e}}$ is the equilibrium concentration of the remaining solute in the solution $\left(\mathrm{mg} \mathrm{L}^{-1}\right)$ and $n$ and $K_{\mathrm{L}}$ are the Freundlich equilibrium constant.

The Temkin (Temkin 1941) is:

$q_{\mathrm{e}}=B \ln \left(\begin{array}{ll}K_{\mathrm{T}} & C_{\mathrm{e}}\end{array}\right)$

where $q_{\mathrm{e}}$ is the amount of sorbate at time and equilibri$\mathrm{um}\left(\mathrm{mg} \mathrm{g}^{-1}\right), K_{\mathrm{T}}\left(\mathrm{L} \mathrm{mg}^{-1}\right)$ is the Temkin equilibrium constant and $B\left(\mathrm{mg} \mathrm{g}^{-1}\right)$ is related with the variation of adsorption energy and $C_{\mathrm{e}}$ is the equilibrium concentration of the remaining solute in the solution $\left(\mathrm{mg} \mathrm{L}^{-1}\right)$.

The model that best adapts to the isotherms of adsorption is the model of Langmuir, in adsorptions of equivalent ions and monolayer on the surface of the adsorbent (Ahmaruzzaman 2010; Seliem et al. 2016).

When isotherm arrived at equilibration in WSA, BSA and PWA at 4 days ( $96 \mathrm{~h}$ ), the solution was filtered through a Prat Dumas glass microfiber filter $(25 \mathrm{~mm}$ and retention micrometry $1.2 \mu \mathrm{m}$ ) to separate the solid from liquid phase. The liquids were collected in clean vials. The concentration of phosphorus was determined using a chromatograph Spectroquant NOVA 60. Figure 1 shows the time that the kinetic needs to reach the equilibrium.

\subsection{Batch Adsorption Experiments}

Adsorption experiments were carried out in batch mode by using different concentrations of sodium hydrogen phosphate $\left(\mathrm{Na}_{2} \mathrm{HPO}_{4}\right)$ on $50 \mathrm{~mL}$ of synthetic

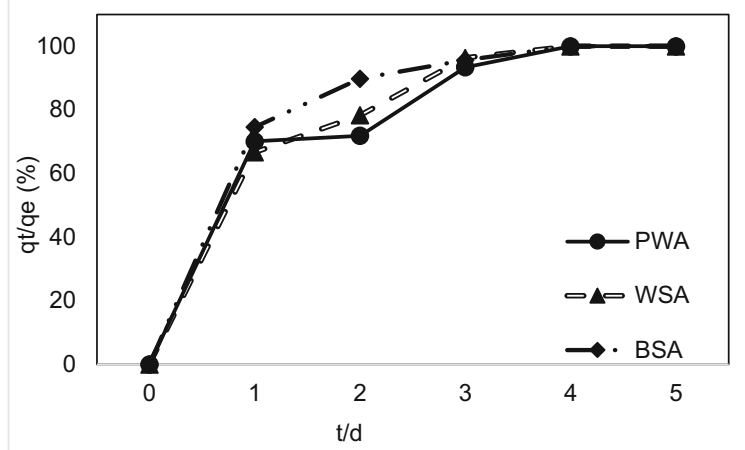

Fig. 1 Kinetic of PWA, WSA and BSA in conical flask at $293 \mathrm{~K}$ wastewater in a $100-\mathrm{mL}$ conical flask and then stirred at $283 \mathrm{~K}, 293 \mathrm{~K}$ and $303 \mathrm{~K}$ of temperature.

Phosphorus stock solution ( $80 \mathrm{mg} \mathrm{L}^{-1}$ ) was prepared by dissolving $0.3704 \mathrm{~g}$ sodium hydrogen phosphate $\left(\mathrm{Na}_{2} \mathrm{HPO}_{4}\right)$ in $1 \mathrm{~L}$ of distilled water. Further serial dilutions were made to have synthetic wastewater of desired phosphorus concentration $(2.5,5,10,15,20$, 25, 30, 40, 50, 60, 70 and $80 \mathrm{mg} \mathrm{L}^{-1}$ ).

Adsorption studies for PWA were carried out with doses $1.5 \mathrm{~g} \mathrm{~L}^{-1}, 2.5 \mathrm{~g} \mathrm{~L}^{-1}$ and $5 \mathrm{~g} \mathrm{~L}^{-1}$, for BSA and WSA with $2.5 \mathrm{~g} \mathrm{~L}^{-1}, 5 \mathrm{~g} \mathrm{~L}^{-1}$ and $10 \mathrm{~g} \mathrm{~L}^{-1}$, all having contact time of $96 \mathrm{~h}$. After adsorption, the solution was filtered through the Prat Dumas glass microfiber filter (25 mm and retention micrometry $1.2 \mu \mathrm{m}$ ) and phosphorus concentration was determined using a chromatograph Spectroquant NOVA 60.

The percentage removal of phosphorus was calculated by using the following formula:

$\%$ Removal efficiency $=\frac{C_{\mathrm{o}}-C_{f}}{C_{\mathrm{o}}} \times 100$

$C_{\mathrm{o}}$ is the initial concentration $\left(\mathrm{mg} \mathrm{L}^{-1}\right)$ and $C_{\mathrm{F}}$ is the final concentration of phosphorus $\left(\mathrm{mg} \mathrm{L}^{-1}\right)$.

\section{Results and Discussion}

\subsection{Characterization of Adsorbent}

The characterization of the different ashes is summarized in Table 2. It can be seen that alkaline earth is the main component in the adsorbents principally calcium and magnesium. In addition, alkalines are present, the main elements being potassium and sodium. There are other metal oxides such as aluminium, iron or copper.

This fact agrees with the contribution of nutrients to the soil by the straw ashes that had been described by Ribó et al. (2017). The low percentage of carbon indicates that these materials are essentially inorganic.

Moreover, the scanning electron micrograph of the adsorbents shows materials with different shapes, sizes and structures are non-crystalline with a heterogenic distribution of particles in the materials (see Fig. 2).

\subsection{Effect of Adsorbent Dose}

The removal of phosphorus was carried out using synthetic wastewater containing 2.5, 5, 7.5, 10, 15, 20, 25, 
Table 2 Physical and chemical properties of the adsorbent materials

\begin{tabular}{|c|c|c|c|}
\hline Samples & WSA & BSA & PWA \\
\hline $\mathrm{pH}_{\mathrm{PZC}}$ & 11.89 & 11.49 & 11.00 \\
\hline \multicolumn{4}{|c|}{ Elementary analysis (wt\%) } \\
\hline Carbon & 1.102 & 0.938 & 0.818 \\
\hline Nitrogen & 0.034 & 0.042 & 0.025 \\
\hline \multicolumn{4}{|c|}{ Composition (wt\%) } \\
\hline $\mathrm{Si}$ & 0.481 & 0.144 & 0.213 \\
\hline $\mathrm{Al}$ & 1.526 & 0.282 & 0.232 \\
\hline $\mathrm{Fe}$ & 1.020 & 0.228 & 0.150 \\
\hline $\mathrm{Mn}$ & 0.041 & 0.022 & 0.012 \\
\hline $\mathrm{Mg}$ & 2.423 & 2.541 & 1.459 \\
\hline $\mathrm{Ca}$ & 17.140 & 8.220 & 6.360 \\
\hline $\mathrm{Na}$ & 1.299 & 1.263 & 2.559 \\
\hline $\mathrm{K}$ & 3.474 & 6.527 & 3.064 \\
\hline $\mathrm{P}$ & 1.961 & 1.235 & 1.173 \\
\hline $\mathrm{Zn}$ & 0.106 & 0.013 & 0.005 \\
\hline $\mathrm{Cu}$ & 0.0393 & 0.0030 & 0.0036 \\
\hline $\mathrm{Li}$ & 0.0051 & n.d. & n.d. \\
\hline $\mathrm{Ni}$ & 0.0010 & n.d. & 0.0019 \\
\hline Co & n.d. & n.d. & 0.0030 \\
\hline $\mathrm{Cd}$ & n.d. & n.d. & n.d. \\
\hline $\mathrm{Cr}$ & 0.00073 & n.d. & n.d. \\
\hline
\end{tabular}

n.d. not detected

$30,40,50,60,65,70,75$ and $80 \mathrm{mg} \mathrm{L}^{-1}$ of phosphorus. Adsorption isotherm experiments were conducted during contact time $96 \mathrm{~h}$. The results obtained show that the amount of phosphorus-removed increases with increasing the adsorbent dosage (see Fig. 3) and during the adsorption process until reaching the equilibrium. This behaviour was also observed by Chen et al. (2016).

In the case of the PWA, the percentage of phosphorus removal varies with the phosphorus-ash ratio (24.84$98.80 \%$ ). With the WSA, the percentage of phosphorus removal varies with the phosphorus-ash ratio (28.58$94.61 \%$ ), and with the BSA, the percentage of phosphorus removal varies with the phosphorus-ash ratio (42.29-98.49\%).

Figure 4 shows that PWA achieves the maximum adsorption $(98.80 \%)$ with a concentration at $5 \mathrm{~g} \mathrm{~L}^{-1}$ and $293 \mathrm{~K}$. A high capacity for phosphorus removal (13.18 $\mathrm{mg} \mathrm{P} \mathrm{g}^{-1}$ ) has been observed with a concentration at $1.5 \mathrm{~g} \mathrm{~L}^{-1}$ and $293 \mathrm{~K}$. Water conductivity varies in the range 271-921 $\mu \mathrm{S} \mathrm{cm}^{-1}$ and increases with ash concentration and phosphate-ash ratio, as demonstrated by Kawakita et al. (2008).

Furthermore, Fig. 5 shows that WSA shows maximum adsorption $(94.61 \%)$ with a concentration at $10 \mathrm{~g} \mathrm{~L}^{-1}$ and $293 \mathrm{~K}$. A high capacity for phosphate removal ( $9.14 \mathrm{mg} \mathrm{P} \mathrm{g}^{-1}$ ) has been observed with a concentration at $2.5 \mathrm{~g} \mathrm{~L}^{-1}$ and $293 \mathrm{~K}$. An ion exchange process has been observed during phosphorus adsorption. Water conductivity varies in the range 470$1413 \mu \mathrm{S} \mathrm{cm}^{-1}$ and increases with ash concentration and phosphorus-ash ratio (Kawakita et al. 2008).

Moreover, Fig. 6 shows that BSA with a concentration at $10 \mathrm{~g} \mathrm{~L}^{-1}$ and $293 \mathrm{~K}$ shows maximum adsorption at $98.49 \%$. A high capacity for phosphorus removal (13.52 $\mathrm{mg} \mathrm{P} \mathrm{g}^{-1}$ ) has been observed with a concentration at $2.5 \mathrm{~g} \mathrm{~L}^{-1}$ and $293 \mathrm{~K}$. An ion exchange process has been observed during phosphorus adsorption. Water conductivity varies in the range $366-1214 \mu \mathrm{S} \mathrm{cm}^{-1}$ and increases with ash concentration and phosphorus-ash ratio (Kawakita et al. 2008).

Finally, PWA, BSA and WSA data indicates that the adsorbed amount of phosphorus increased with the increasing dose $\left(\mathrm{g} \mathrm{L}^{-1}\right)$ of adsorbent. Thus, with the increasing adsorbent amount, the decreasing adsorption capacity was due to the increasing interface area. But for the adsorption of phosphorus, more ions went into the adsorbent by way of swelling and water absorption by the adsorbent. So, when the ash dose was increased, an increase in phosphorus removal was also observed, as some other authors have also documented for other ash materials (Ma et al. 2011; Vassileva and Voikova 2009).

\subsection{Adsorption Isotherms and Effect of Temperature}

The temperatures of $283 \mathrm{~K}, 293 \mathrm{~K}$ and $303 \mathrm{~K}$ were chosen because the temperature of wastewater coming to rivers and lagoons in the Mediterranean area is normally within these chosen ranges. Martín et al. (2013) measured average temperatures of $291.75 \mathrm{~K}$. In another study, Soria (2006) measured average temperatures of $291.85 \pm 6.9 \mathrm{~K}$ for the period between 1986 and 1998 and $292.55 \pm 6.2 \mathrm{~K}$ for the period between 1997 and 2000.

The study of the effects of temperature was carried out. The adsorbent contacts with the phosphorus until reaching a constant equilibrium, which happens after 4 days (96 h). The removal of phosphorus was carried out using synthetic wastewater containing $2.5,5,7.5$, $10,15,20,25,30,40,50,60,65,70,75$ and $80 \mathrm{mg} \mathrm{L}^{-1}$ 
Fig. 2 Scanning electron

micrograph of WSA (a), BSA (b)

and PWA (c) adsorbents
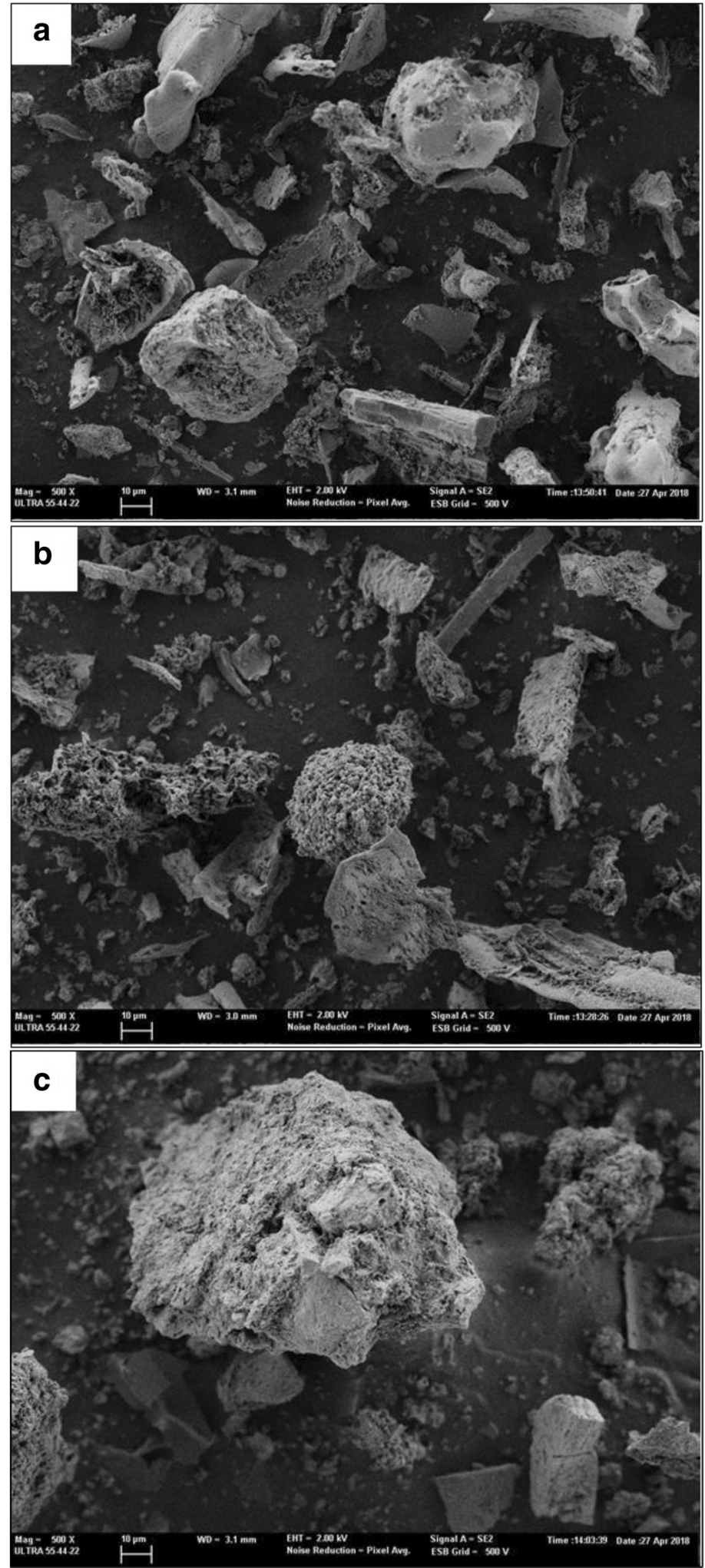
Fig. $3 q_{\max }$ of WSA and BSA in conical flask with $2.5,5$ and $10 \mathrm{~g} \mathrm{~L}^{-1}$ and $q_{\max }$ of PWA in conical flask with $1.5,2.5$ and $5 \mathrm{~g} \mathrm{~L}^{-1}$, at $293 \mathrm{~K}$

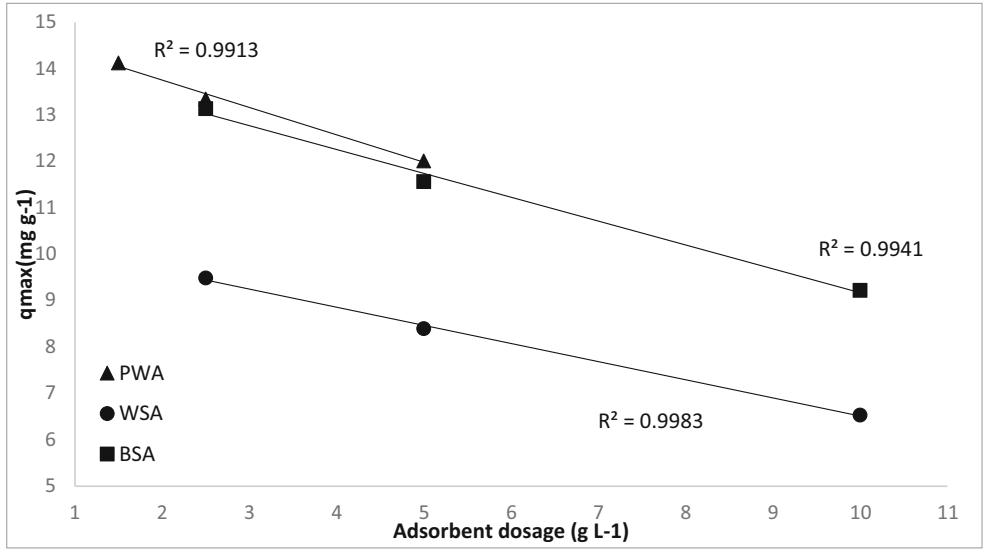

of phosphorus. Figure 7 shows the $q_{\max }$ of the three materials considering that the experiments were conducted at different temperatures $(283 \mathrm{~K}, 293 \mathrm{~K}$ and $303 \mathrm{~K}$ ) and with $5 \mathrm{~g} \mathrm{~L}^{-1}$ for WSA and BSA and $2.5 \mathrm{~g} \mathrm{~L}^{-1}$ for PWA.

The adsorption isotherms were carried out with the same amounts of phosphorus so as not to vary the electrical conductivity of the solution, because of this the amounts of adsorbent vary so that the adsorption isotherm reaches equilibrium.

The obtained results demonstrate for PSA that the temperature increases the phosphorus removal from 96.99 to $97.31 \%$, with a concentration at $2.5 \mathrm{~g} \mathrm{~L}^{-1}$ and $303 \mathrm{~K}$. Figure 8 shows the maximum adsorption at $97.31 \%$. The best capacity for phosphorus removal (15.7 $\mathrm{mg} \mathrm{P} \mathrm{g}^{-1}$ ) was observed with a concentration at $2.5 \mathrm{~g} \mathrm{~L}^{-1}$ and $303 \mathrm{~K}$ for PSA. Water conductivity varied

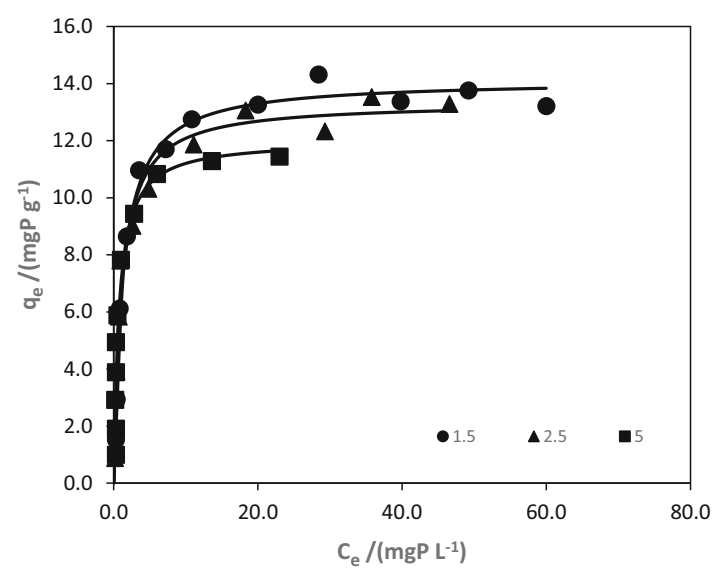

Fig. 4 PWA in conical flask with 1.5, 2.5 and $5 \mathrm{~g} \mathrm{~L}^{-1}$ and 2.5, 5, $10,15,20,25,30,40,50,60,65,70$ and $80 \mathrm{mg} \mathrm{L}^{-1}$ of phosphorus, at $293 \mathrm{~K}$ in the range of 361-738 $\mu \mathrm{S} \mathrm{cm}^{-1}$ and increases with the temperature, similar to other authors (Mor et al. 2016).

Furthermore, for WSA, the temperature increases the phosphorus removal from 83.05 to $93.94 \%$, with a concentration at $5 \mathrm{~g} \mathrm{~L}^{-1}$ and $303 \mathrm{~K}$. The maximum adsorption is at $93.94 \%$, as shown in Fig. 9. The worst capacity for phosphorus removal $\left(9.57 \mathrm{mg} \mathrm{P} \mathrm{g}^{-1}\right)$ has been observed with a concentration at $5 \mathrm{~g} \mathrm{~L}^{-1}$ and $303 \mathrm{~K}$ for WSA. Water conductivity varies in the range 676$1147 \mu \mathrm{S} \mathrm{cm}^{-1}$ and increases with the temperature. This behaviour is also observed by El-Naas et al. (2010) and Mor et al. (2016).

Moreover, for BSA, the temperature increases from 95.85 to $97.5 \%$ the phosphorus removal, with a concentration at $5 \mathrm{~g} \mathrm{~L}^{-1}$ and $303 \mathrm{~K}$. Figure 10 shows the maximum adsorption at $97.5 \%$. The second best capacity for phosphorus removal (13.06 $\mathrm{mg} \mathrm{P} \mathrm{g}^{-1}$ ) has been

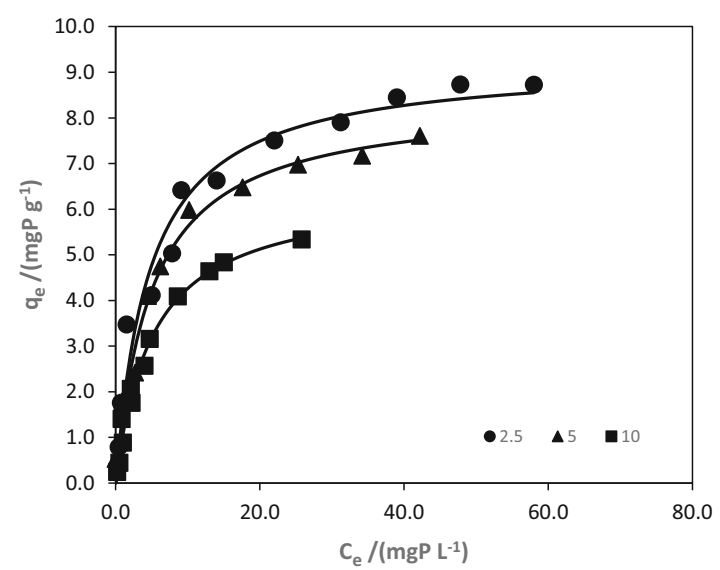

Fig. 5 WSA in conical flask with 2.5, 5 and $10 \mathrm{~g} \mathrm{~L}^{-1}$ and 2.5, 5, $10,15,20,25,30,40,50,60,65,70$ and $80 \mathrm{mg} \mathrm{L}^{-1}$ of phosphorus, at $293 \mathrm{~K}$ 


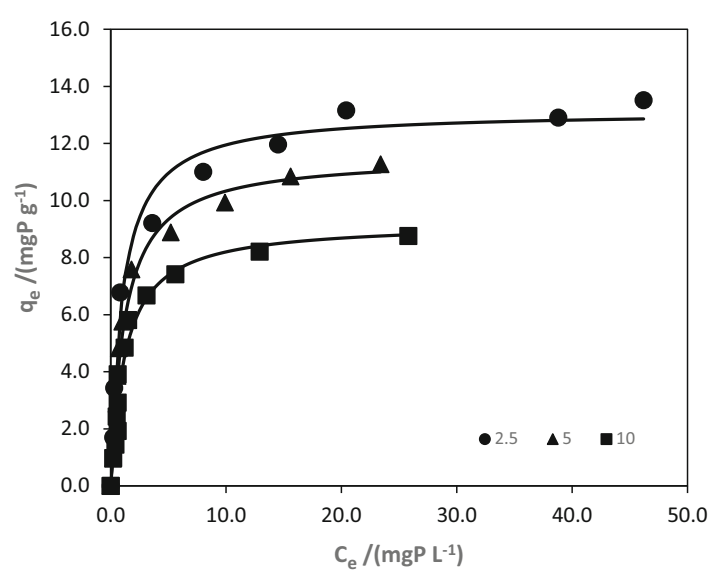

Fig. 6 BSA in conical flask with $2.5,5$ and $10 \mathrm{~g} \mathrm{~L}^{-1}$ and 2.5, 5, $10,15,20,25,30,40,50,60,65,70$ and $80 \mathrm{mg} \mathrm{L}^{-1}$ of phosphorus, at $293 \mathrm{~K}$

observed with a concentration at $5 \mathrm{~g} \mathrm{~L}^{-1}$ and $303 \mathrm{~K}$ for BSA. Water conductivity varies in the range 725 $997 \mu \mathrm{S} \mathrm{cm}^{-1}$ and increases with the temperature, following also the results obtained by Mor et al. (2016).

Table 3 summarizes the isotherm models for adsorption of phosphorus for the three ashes at the different temperatures tested. Consequently, PWA, BSA and WSA data indicate that adsorption increases when temperature increases. This finding matches other studies that confirm that increasing the temperature increases the adsorption efficiency (El-Naas et al. 2010; Mor et al. 2016). In addition, Table 3 shows the fitted parameters of the three studied isotherm models, including coefficients of determination $\left(R^{2}\right)$. According to the data obtained, Freundlich isotherm model presents the worst value $R^{2}$ in all cases. The lower difference Akaike's

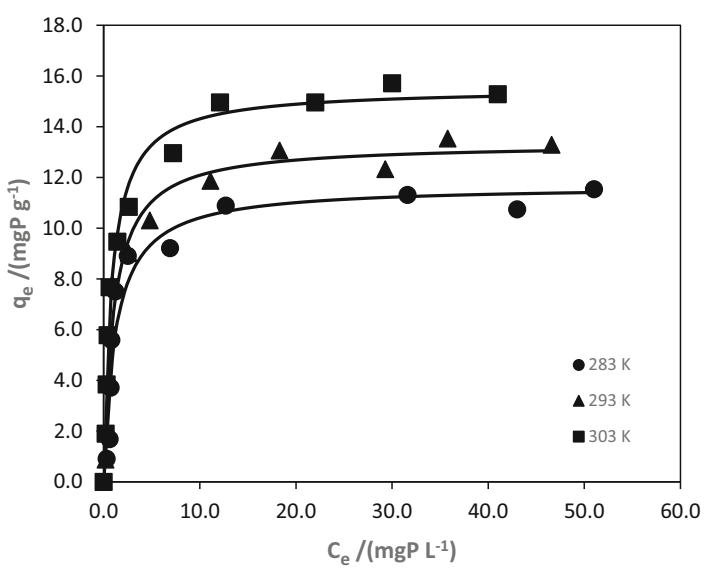

Fig. 8 PWA in conical flask with $2.5 \mathrm{~g} \mathrm{~L}^{-1}$ and $2.5,5,10,15,20$, $25,30,40,50,60,70$ and $80 \mathrm{mg} \mathrm{L}^{-1}$ of phosphorus, at 283,293 and $303 \mathrm{~K}$

Information Criterion (AIC) (Motulsky and Healey 2005) value was obtained with Langmuir isotherm model. Hence, this model is the most probable.

The theoretical Langmuir equation (Langmuir 1916) was originally applied to the adsorption of gases on a solid surface and, subsequently, to the liquid phase. The dynamic equilibrium of adsorption is related with the rate constants of adsorption and desorption. At equilibrium there is no net change, the sum of these two rates is zero, and the constant of this equilibrium (ratio between the adsorption and desorption rate constants) is the Langmuir equilibrium constant $\left(K_{\mathrm{L}}\right)$. Assuming that, $K_{\mathrm{L}}$ is essentially an equilibrium constant of the overall process that takes place during the phosphorus adsorption. So, its temperature dependence can be used to determine the
Fig. $7 q_{\max }$ of WSA and BSA in conical flask with $5 \mathrm{~g} \mathrm{~L}^{-1}$ and $q_{\text {max }}$ of PWA in conical flask with $2.5 \mathrm{~g} \mathrm{~L}^{-1}$, at 283,293 and $303 \mathrm{~K}$

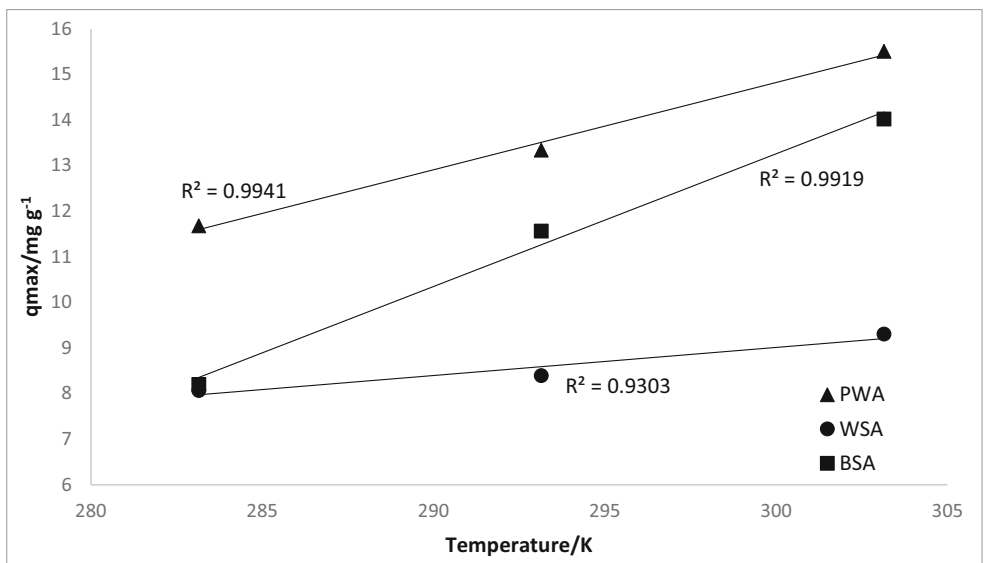




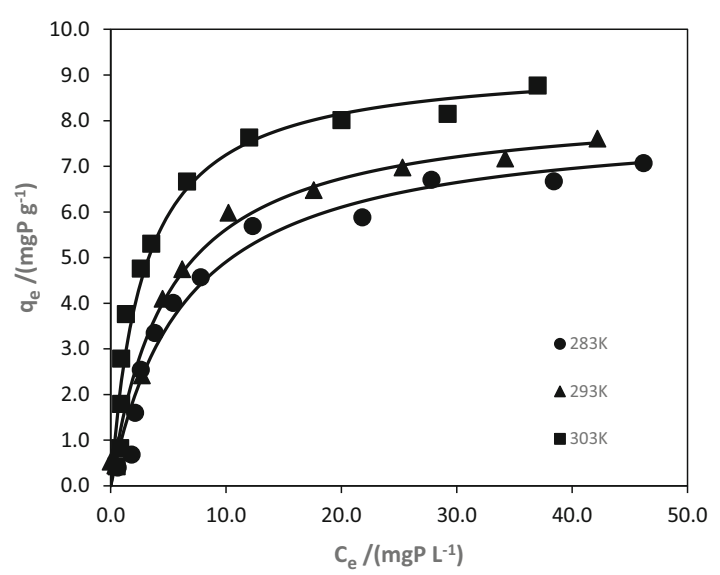

Fig. 9 WSA in conical flask with $5 \mathrm{~g} \mathrm{~L}^{-1}$ and 2.5, 5, 10, 15, 20, $25,30,40,50,60,70$ and $80 \mathrm{mg} \mathrm{L}^{-1}$ of phosphorus, at 283,293 and $303 \mathrm{~K}$

isosteric enthalpy of adsorption, $\Delta_{\mathrm{ad}} H^{\circ}$, using the Van't Hoff equation (Van't Hoff 1887):

$$
\left(\frac{\partial \ln K}{\partial(1 / T)}\right)_{\theta}=-\frac{\Delta_{\mathrm{ad}} H^{\circ}}{R}
$$

where ln denotes natural logarithm, $K$ is the equilibrium constant, $T$ is the temperature, $\theta$ is the coating fraction, $\Delta_{\mathrm{ad}} H^{\circ}$ is the enthalpy of adsorption and $R$ is the ideal gas constant.

Figure 11 shows the plot of the Van't Hoff equation of the experimental data. According to Eq. 5, the slope of each curve represents the isosteric enthalpy of

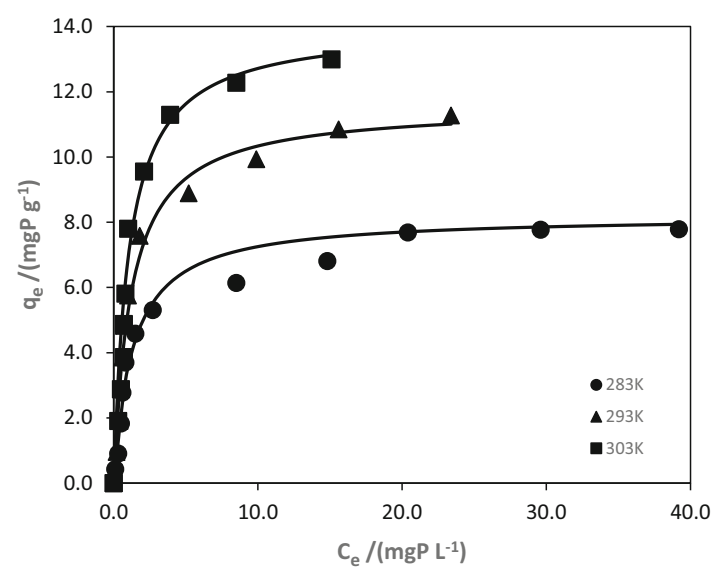

Fig. 10 BSA in conical flask with $5 \mathrm{~g} \mathrm{~L}^{-1}$ and 2.5, 5, 10, 15, 20, $25,30,40,50,60,70$ and $80 \mathrm{mg} \mathrm{L}^{-1}$ of phosphorus, at 283,293 and $303 \mathrm{~K}$ adsorption for each adsorbent. The linearity of the curves is quite good, as shown by the high values of the coefficients of determination. The calculated values of the enthalpy are $13.38 \mathrm{~kJ} \mathrm{~mol}^{-1}, 8.49 \mathrm{~kJ} \mathrm{~mol}^{-1}$ and $29.25 \mathrm{~kJ} \mathrm{~mol}^{-1}$ for PWA, BSA and WSA adsorbents, respectively. These positive values indicate the endothermic nature of the global process that takes place during the phosphorus adsorption.

The reaction is endothermic. The adsorption capacity depends on the energy of the process. The greater the adsorption efficiency, the higher the temperature, which is what provides energy to the adsorption process.

\section{Conclusions}

This study examined the adsorption of phosphorus by paulownia wood ash (PWA), burley straw ash (BSA) and wheat straw ash (WSA) under varying conditions. The results obtained have demonstrated the high capacity for phosphorus removal of the three tested ashes.

The dates obtained in characterization in the adsorbents indicate that the main elements are calcium and magnesium. On the other hand, the low percentage of carbon indicates that these materials are essentially inorganic.

Moreover, the results also demonstrated that the kinetic process lasted at least $96 \mathrm{~h}$, and that the Langmuir adsorption model showed a better correlation with experimental equilibrium data.

The percentage of phosphorus removal varied significantly with the phosphorus-ash ratio: when the ash dose was increased, an increase in phosphorus removal was also observed.

With the PWA, the percentage of phosphorus removal varies (24.84-98.80\%). With the WSA, the percentage of phosphorus removal varies (28.58-94.61\%), and with the BSA, the percentage of phosphorus removal varies (42.29-98.49\%).

Furthermore, increasing the temperature led to an increase of phosphorus removal and the positive values indicate the endothermic process.

So, PWA showed the best adsorption capacity of the three tested adsorbents, eliminating up to $12.01 \mathrm{mg} \mathrm{g}^{-1}$ of phosphorus from synthetic wastewater with a concentration of $5 \mathrm{~g} \mathrm{~L}^{-1}$ of adsorbent at $293 \mathrm{~K}$ in $96 \mathrm{~h}$. BSA reached up to $11.96 \mathrm{mg} \mathrm{g}^{-1}$ elimination of phosphorus with an adsorbent 
Table 3 Isotherm models for adsorption of phosphorus for three materials at different temperatures

\begin{tabular}{|c|c|c|c|c|c|c|c|c|c|c|}
\hline \multirow[t]{3}{*}{ Models } & & \multicolumn{3}{|c|}{ Paulownia } & \multicolumn{3}{|l|}{ Wheat } & \multicolumn{3}{|c|}{ Barley } \\
\hline & & \multicolumn{3}{|l|}{$T(\mathrm{~K})$} & \multicolumn{3}{|l|}{$T(\mathrm{~K})$} & \multicolumn{3}{|l|}{$T(\mathrm{~K})$} \\
\hline & & 283 & 293 & 303 & 283 & 293 & 303 & 283 & 293 & 303 \\
\hline \multirow[t]{4}{*}{ Langmuir } & $q_{\max }\left(\mathrm{mg} \mathrm{g}^{-1}\right)$ & 11.68 & 13.34 & 15.51 & 8.07 & 8.40 & 9.31 & 8.20 & 11.56 & 14.03 \\
\hline & $K_{\mathrm{L}}\left(\mathrm{L} \mathrm{mg}^{-1}\right)$ & 0.82 & 0.96 & 1.19 & 0.155 & 0.202 & 0.353 & 0.76 & 0.83 & 0.97 \\
\hline & $R^{2}$ & 0.92 & 0.97 & 0.98 & 0.97 & 0.99 & 0.96 & 0.98 & 0.98 & 0.97 \\
\hline & DAIC & 0.0 & & & 0.0 & & & 0.0 & & \\
\hline \multirow[t]{4}{*}{ Freundlich } & $K_{\mathrm{F}} *$ & 5.19 & 5.94 & 7.52 & 1.77 & 2.06 & 2.89 & 3.20 & 4.72 & 5.94 \\
\hline & $n$ & 0.22 & 0.24 & 0.22 & 0.39 & 0.37 & 0.33 & 0.27 & 0.31 & 0.33 \\
\hline & $R^{2}$ & 0.76 & 0.86 & 0.88 & 0.90 & 0.93 & 0.87 & 0.90 & 0.89 & 0.84 \\
\hline & DAIC & 39.3 & & & 41.4 & & & 47.4 & & \\
\hline \multirow[t]{4}{*}{ Tempkin } & $B\left(\mathrm{mg} \mathrm{g}^{-1}\right)$ & 1.91 & 2.20 & 2.46 & 1.69 & 1.61 & 1.89 & 1.33 & 2.22 & 3.03 \\
\hline & $K_{\mathrm{T}}\left(\mathrm{L} \mathrm{mg} g^{-1}\right)$ & 13.49 & 15.22 & 22.82 & 1.69 & 2.86 & 3.73 & 12.67 & 9.39 & 7.44 \\
\hline & $R^{2}$ & 0.84 & 0.94 & 0.95 & 0.96 & 0.98 & 0.95 & 0.97 & 0.96 & 0.93 \\
\hline & DAIC & 15.3 & & & 35.5 & & & 14.8 & & \\
\hline
\end{tabular}

Comparison between adsorbents with their respective Langmuir, Freundlich and Tempkin isotherms in 283, 293 and $303 \mathrm{~K}$ according to the Akaike Information Criteria (AIC) and $R^{2}$

*Units of $K_{\mathrm{F}}\left(\mathrm{mg}^{1-(1 / n)} \mathrm{L}^{1 / n} \mathrm{~g}^{-1}\right)$

concentration of $5 \mathrm{~g} \mathrm{~L}^{-1}$ at $293 \mathrm{~K}$ in the same period. WSA reached up to $8.39 \mathrm{mg} \mathrm{g}^{-1}$ with an adsorbent concentration of $5 \mathrm{~g} \mathrm{~L}^{-1}$ at $293 \mathrm{~K}$.

Finally, the conducted research has demonstrated that after the production of energy in a biomass plant, the fly ashes of wood and/or straw can be reused to improve water quality by reducing the amount of phosphorus in contaminated water in rivers, lakes or lagoons, providing an environmentally sound low-cost remedial treatment. Once the adsorption process is finished, the phosphorus-enriched ash waste generated could then finally act as a valorised fertilizer that farmers could reuse in their fields, fulfilling the objectives of the circular economy.
Fig. 11 Thermodynamic plot for adsorption of phosphorus at 283 , 293 and $303 \mathrm{~K}$

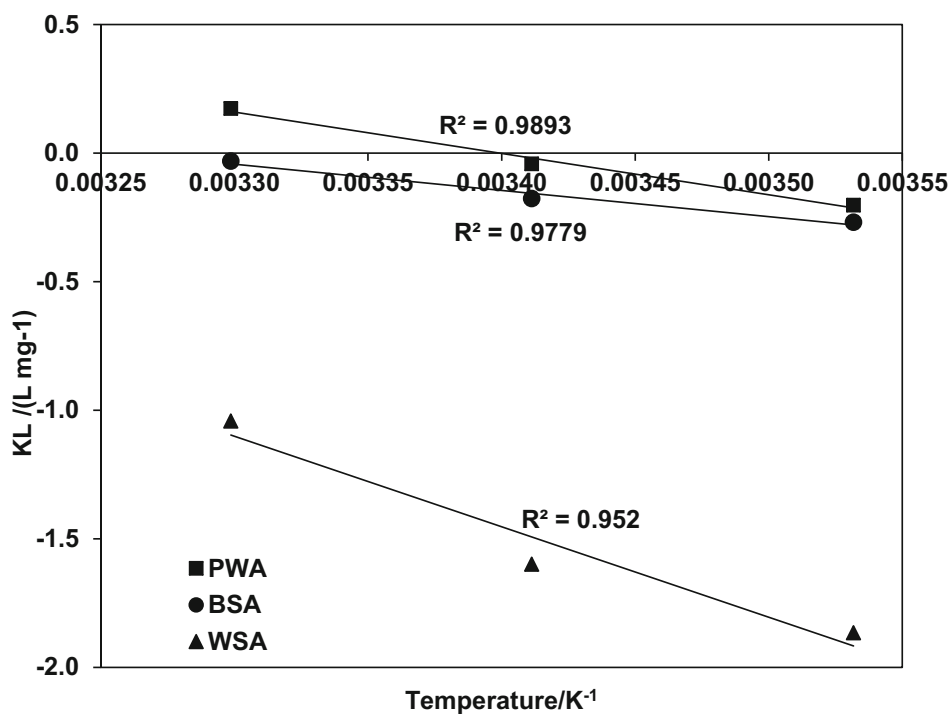




\section{References}

Ahmaruzzaman, M. (2010). A review on the utilization of fly ash. Progress in Energy and Combustion Science, 36(3), 327363. https://doi.org/10.1016/j.pecs.2009.11.003.

AOAC (Association of Official Agricultural Chemists). (2000). Gaithersburg: Editor, Dr William Horwitz. 17o edición. Publicado por AOAC internacional. Gaithersburg, Maryland USA.

Chen, Y., Wang, F., Duan, L., Yang, H., \& Gao, J. (2016). Tetracycline adsorption onto rice husk ash, an agricultural waste: its kinetic and thermodynamic studies. Journal of Molecular Liquids, 222, 487-494. https://doi.org/10.1016/j. molliq.2016.07.090.

Deboni, T. L., Simioni, F. J., Brand, M. A., \& Lopes, G. P. (2018). Evolution of the quality of forest biomass for energy generation in a cogeneration plant. Renewable Energy. https://doi. org/10.1016/j.renene.2018.09.039.

El-Naas, M. H., Al-Zuhair, S., \& Alhaija, M. A. (2010). Reduction of COD in refinery wastewater through adsorption on datepit activated carbon. Journal of Hazardous Materials, 173(13), 750-757. https://doi.org/10.1016/j.jhazmat.2009.09.002.

European Commission (1991). Council Directive 91/271/EC of 21 May 1991 concerning urban waste-water treatment. Official Journal of the European Union, L 135, 30.5.1991,40-52.

European Commission. (2009). Directive 2009/28/EC of the European Parliament and of the Council of 23 April 2009 on the promotion of the use of energy from renewable sources. Official Journal of the European Union, L, 140(16), 16-62.

European Commission (2014). EU cereal farms report 2013. European Union, Brussels, pp. 122.

Fernández-Puratich, H., Oliver-Villanueva, J. V., Valiente, M., Verdú, S., \& Albert, N. (2014). Development pellets from three woody species under Mediterranean conditions. Madera y Bosques, 20(3), 95-109.

Fernández-Puratich, H., Oliver-Villanueva, J. V., Lerma Arce, V., \& Raigón Jiménez, M. D. (2017). A study of Paulownia spp. as a short-rotation forestry crop for energy uses in Mediterranean conditions. Madera y Bosques, 23(3), 1527. https://doi.org/10.21829/myb.2017.2331416.

Freundlich, H. (1906). Über die Adsorption in Lösungen. Zeitschrift für Physikalische Chemie, 57, 385-470.

García-Maraver, A., Zamorano, M., Ramos-Ridao, A., \& Díaz, L. F. (2012). Analysis of olive grove residual biomass potential for electric and thermal energy generation in Andalusia (Spain). Renewable and Sustainable Energy Reviews, 16(1), 745-751. https://doi.org/10.1016/j.rser.2011.08.040.

García-Nieto, P. J., García-Gonzalo, E., Alonso Fernández, J. R., \& Díaz Muñiz, C. (2016). Using evolutionary multivariate adaptive regression splines approach to evaluate the eutrophication in the Pozón de la Dolores lake (Northern Spain). Ecological Engineering, 94, 136-151. https://doi. org/10.1016/j.ecoleng.2016.05.047.

Girón, R. P., Ruiz, B., Fuente, E., Gil, R. R., \& Suárez-Ruiz, I. (2013). Properties of fly ash from forest biomass combustion. Fuel, 114, 71-77. https://doi.org/10.1016/j.fuel.2012.04.042.

Gislev, M., Grohol, M., Mathieux, F., Ardente, F., Bobba, S., Nuss, P., et al. (2018). Report on critical raw materials and the circular economy. Luxembourg: Luxembourg : Publications Office. https://doi.org/10.2873/331561.

Ingerslev, M., Skov, S., Sevel, L., \& Pedersen, L. B. (2011). Element budgets of forest biomass combustion and ash fertilisation - a Danish case-study. Biomass and Bioenergy, $35,2697-2704$.

Kawakita, H., Harada, H., Biswas, B. K., Ohto, K., Inoue, K., \& Ghimire, K. N. (2008). Removal and recovery of phosphorus from water by means of adsorption onto orange waste gel loaded with zirconium. Bioresource Technology. https://doi. org/10.1016/j.biortech.2008.04.015.

Krasuska, E., Cadórniga, C., Tenorio, J.L., Testa, G., Scordia, D. (2010). Potential land availability for energy crops production in Europe. Biofuels, Bioproducts and Biorefining 4(6) Special Issue: Biofuels for Europe: 658-673. https://doi. org/10.1002/bbb.259.

Langmuir, I. (1916). The constitution and fundamental properties of solids and liquids. Part I. Journal of the American Chemical Society, 38(9), 2221-2295. https://doi. org/10.1021/ja02268a002.

Liu, J., Su, Y., Li, Q., Yue, Q., \& Gao, B. (2013). Preparation of wheat straw based superabsorbent resins and their applications as adsorbents for ammonium and phosphate removal. Bioresource Technology, 143, 32-39. https://doi.org/10.1016 j.biortech.2013.05.100.

Ma, Z., Li, Q., Yue, Q., Gao, B., Li, W., Xu, X., \& Zhong, Q. (2011). Adsorption removal of ammonium and phosphate from water by fertilizer controlled release agent prepared from wheat straw. Chemical Engineering Journal, 171(3), 1209-1217. https://doi.org/10.1016/j.cej.2011.05.027.

Martín, M., Oliver, N., Hernández-Crespo, C., Gargallo, S., \& Regidor, M. C. (2013). The use of free water surface constructed wetland to treat the eutrophicated waters of lake L'Albufera de Valencia (Spain). Ecological Engineering, 50, 52-61. https://doi.org/10.1016/j.ecoleng.2012.04.029.

Mor, S., Chhoden, K., \& Ravindra, K. (2016). Application of agrowaste rice husk ash for the removal of phosphate from the wastewater. Journal of Cleaner Production, 129, 673-680. https://doi.org/10.1016/j.jclepro.2016.03.088.

Motulsky, H., Healey, GF. (2005) Fitting models to biological data using linear and nonlinear regression. Oxford University. Press New York. https://doi.org/10.1002/pst.167.

Ortiz de Zárate, I., Ezcurra, A., Lacaux, J. P., Van Dinh, P., \& de Argandoña, J. D. (2005). Pollution by cereal waste burning in Spain. Atmospheric Research, 73(1-2), 161-170. https://doi. org/10.1016/J.ATMOSRES.2004.07.006.

Ribó, M., Albiach, R., Pomares, F., \& Canet, R. (2017). Alternativas de gestión de la paja de arroz en la albufera de Valencia. Vida Rural, 430, 56-60.

Santamarta, J. C., Jarabo, F., Rodríguez-Martín, J., Arraiza, M. P., \& López, J. V. (2014). Analysis and potential of use of biomass energy in Canary Islands, Spain. IERI Procedia, 8 , 136-141. https://doi.org/10.1016/j.ieri.2014.09.023.

Schils, R., Olesen, J. E., Kersebaum, K.-C., Rijk, B., Oberforster, M., Kalyada, V., et al. (2018). Cereal yield gaps across Europe. European Journal of Agronomy, 101, 109-120. https://doi.org/10.1016/j.eja.2018.09.003.

Seliem, M. K., Komarneni, S., \& Abu Khadra, M. R. (2016). Phosphate removal from solution by composite of MCM41 silica with rice husk: kinetic and equilibrium studies. 
Microporous and Mesoporous Materials, 224, 51-57. https://doi.org/10.1016/j.micromeso.2015.11.011.

Senelwa, K., \& Sims, R. E. H. (1999). Fuel characteristics of short rotation forest biomass. Biomass and Bioenergy, 17(2), 127140. https://doi.org/10.1016/S0961-9534(99)00035-5.

Schollenberger, C. J., \& Simon, R. H. (1945). Determination of exchange capacity and exchangeable bases in soilammonium acetate method. Soil Science, 59, 13-24.

Soria, J. M. (2006). Past, present and future of la Albufera of Valencia Natural Park. Limnetica, 25(1-2), 135-142.

Soria, J. M., Miracle, M. R., \& Vicente, E. (1987). Aporte de nutrientes y eutrofización de la Albufera de Valencia. Limnetica, 3(December), 227-242.

Temkin, M. I. (1941). Adsorption equilibrium and the kinetics of processes on nonhomogeneous surfaces and in the interaction between adsorbed molecules. Zhurnal Fiziche- skoi Khimii, 15, 296-332.

Thevannan, A., Mungroo, R., \& Niu, H. C. (2010). Biosorption of nickel with barley straw. Bioresource Technology, 101(6), 1776-1780. https://doi.org/10.1016/j.biortech.2009.10.035.

Ubeda Delgado, J., \& Antolín Giraldo, G. (1995). Energy possibilities from forest residues in the region of Castilla y León in Spain. Biomass and Bioenergy, 8(1), 21-28. https://doi. org/10.1016/0961-9534(94)E0030-V.
Van't Hoff, J.H. (1887). Zeitschrift fur physikalische Chemie vol. 1, pp. 481-508.

Vassileva, P., \& Voikova, D. (2009). Investigation on natural and pretreated Bulgarian clinoptilolite for ammonium ions removal from aqueous solutions. Journal of Hazardous Materials, 170(2-3), 948-953. https://doi.org/10.1016/j. jhazmat.2009.05.062.

Walkley, A., \& Black, I. A. (1934). An examination of the degtjareff method for determining soil organic matter, and a proposed modification of the chromic acid titration method. Soil Science, 37(1), 29-38. https://doi.org/10.1097 /00010694-.

Zegada-Lizarazu, W., Elbersen, H.W., Cosentino, L., Zatta, A., Alexopoulou, E., Monti, A. (2010). Agronomic aspects of future energy crops in Europe. Biofuels, Bioproducts and Biorefining Special Issue: Biofuels for Europe, 4(6), 674691. https://doi.org/10.1002/bbb.242. 